\title{
Photovoltaic Sun Energy Supporting the Health Services
}

MD Fé Fernández Hernández

AuxiliaryProfessor, Faculty of Medical Science "10 de Octubre", University of Medical Science of Havana.

Corresponding Author: MD Fé Fernández Hernández, AuxiliaryProfessor, University of Medical Science of Havana Faculty of Medical Science

"10 de Octubre"

Received Date: October 30, 2020; Accepted Date: November 20, 2020; Published Date; January $02,2021$.

Citation: MD Fé Fernández Hernández, Photovoltaic sun energy supporting the health services. J. Clin Case Rep and Stud. 2(1). Doi:

$10.31579 / 2690-8808 / 051$

Copyright: (C) 2021 MD Fé Fernández Hernández, This is an open-access article distributed under the terms of the Creative Commons Attribution License, which permits unrestricted use, distribution, and reproduction in any medium, provided the original author and source are credited

\section{Abstract}

Background. In Cuba all health services are covered by the fiscal resources. That's why the Cuban government most takes heavy decisions to support the transportation and electrician services for health services. The majority from the electricity generated in Cuba is obtained by gross petroleum. Then, the health services and the patient's satisfaction are close related to the importation of gross petroleum to support the electrician and the health services transportation demand. The use of photovoltaic sun energy contributes to reduce the electrician demand generated by fossil fuel, to reduce the importation of gross petroleum to generate electricity and the save in international currency obtained may be used to cover the importation costs related to transportation services for the health services.

Objective. To value the use of photovoltaic sun energy to support the hospital services in Havana.

Materials and methods. Was made a descriptive research about the benefits utilizing the photovoltaic sun energy to support the hospital services in Havana. As theorical methods were utilized the inductive - deductive, the comparative and the historical - logical. As empiric methods were used the document and bibliographic research and the arithmetic calculus.

Results. If these hospitals considered should install 5000 photovoltaic cell, they should generate 236.25 MW during 350 days at year. This electricity represents the substitution of 65677.5 MT of this fossil fuel annually.

Conclusions. Photovoltaic sun energy shows several benefits for developing countries in tropical zones as Cuba. The example showed before should be taken account in health systems of tropical countries as example to reduce the health services costs and increase the patient satisfaction too.

Key words: health services; photovoltaic sun energy

\section{Background:}

The Cuban health system plays a decisive role in the social and human develop. It value is over the national limits because of the good results obtained out of Cuba. These reasons are justifying the need to guarantee the supporting and continuity from these services. [1]

These conditions are especially significant during hurricanes and other weather disturbs. In case like these the support from the electrician services can be relevant in the health services sustainability. However, the instability and absence in some case from the electrician services during hurricanes, for example, put limitations to the health system capability to offer their services. [2]

In Cuba all health services are covered by the fiscal resources. Then, the Cuban government most take heavy decisions to support the transportation and electrician services for health services. These conditions are especially significant in Havana, the capital. [3]

In this region the health services are more demanded because the capital has the biggest population. This condition is more relevant during the recuperation process from the COVID-19. Also, inside the health institution is usually that transportation services are more demanded than the institution capability. [4]

The conventional transportation equipment used carry to increase the use of fossil fuel. Close to the increasing demand of electrician services in hospitals, the Cuban economy must increase the importation of gross petroleum to support the transportation and electricity services for hospitals. This condition may mean an important pressure over the Cuban economy with evident consequences over the patient's satisfaction. [5]

The majority from the electricity generated in Cuba is obtained by gross petroleum. Then, the health services and the patient's satisfaction are close related to the importation of gross petroleum to support the electrician and the health services transportation demand. However, the viability of international currency to cover the importations is always limited. In consequence the health services support are given by this real viability too. [6]

As Cuba, the most developing countries are in tropical zones. This means that Cuba is receiving more sun energy. Agree to this condition the highest Cuba management is promoting the use of photovoltaic sun energy as complement and substitution of the electrician energy obtained 
by gross petroleum. In this case, the use of photovoltaic sun energy contributes to reduce the electrician demand generated by fossil fuel, to reduce the importation of gross petroleum to generate electricity and the save in international currency obtained may be used to cover the importation costs related to transportation services for the health services. [7]

\section{Objective:}

To value the use of photovoltaic sun energy to support the hospital services in Havana.

\section{Materials and methods:}

Was made a descriptive research about the benefits utilizing the photovoltaic sun energy to support the hospital services in Havana. As theorical methods were utilized the inductive - deductive, the comparative and the historical - logical. As empiric methods were used the document and bibliographic research and the arithmetic calculus.

\section{Results:}

Cuba industry produces photovoltaic cell to generate electricity. Agree to the technology characteristic and the Cuba conditions, each cell may generate $135 \mathrm{Kw}$ at day if are front of the south. Each cell has an area of $1.6 \mathrm{~m}^{2}$. Considering the necessary space between each cell the whole area needed is close to $2 \mathrm{~m}^{2}$ by cell [8]

Havana's hospitals as "Calixto García", "Salvador Allende" and "10 de Octubre" have especial condition for an intensive use of this technology. These hospitals are using extensively the land where are localized. Much from the floor area is free and may be able to use photovoltaic cell to generate electricity. The electricity obtained should cover partially the hospital consumption and should reduce the fiscal spends by this way. [9] If these hospitals should use $10000 \mathrm{~m}^{2}$ of area to install 5000 photovoltaic cell, this means the generation of $236.25 \mathrm{MW}$ during 350 days at year. The Cuban electrician system needs 278 grams of gross petroleum to generate $1 \mathrm{Kw}$. The electricity obtained from the photovoltaic cell represents the substitution of 65677.5 MT of this fossil fuel annually. [10] The expected tendency from the gross petroleum in the international market is to increase. If these hospital could have these photovoltaic cell installed ending 2020 for example, the save because of the no importation of gross petroleum should be around the 300 thousand USD. This amount should be sufficient to cover the importation of electric car for health services support the transportation services of these hospitals. The electrician obtained from the photovoltaic cell should cover the electric cars demand and the other electricity produced should contribute to reduce spends in electricity generated with gross petroleum.[11]

This situation don't means that these hospitals will be necessarily selfsufficient in the electricity consumption. Nevertheless, all benefits obtained from the intensive use of the sun energy to generate electricity motives to utilize it strategically to reduce the health services costs and as save cause in international currency too.

\section{Conclusions:}

Photovoltaic sun energy shows several benefits for developing countries in tropical zones as Cuba. The example showed before should be taken account in health systems of tropical countries as example to reduce the health services costs and increase the patient satisfaction too.

\section{References}

1) Gómez-Dantés O. (2018) Cuba's health system: hardly an example to follow. Health Policy and Planning; (33): 760-761

2) Zakrison TL, Valdés DM, Shultz JM. (2020).The Medical, Public Health, and Emergency Response to the Impact of 2017 Hurricane Irma in Cuba. Disaster Medicine and Public Health Preparedness. Cambridge University Press; 14(1):10-17
3) Sánchez González E, Fernández Hernández F. (2019). The Smoking Fiscal Space in Cuba. Journal of Clinical and Medical Research; 1(3):1-5

4) Pérez Cortes M. O. Taller Energías Renovables y Eficiencia Energética en la Rehabilitación de los Centros Históricos. Energía y tú. 2018; 2(82):31-35

5) Mario Alberto Arrastía-Avila and Lisa M. Glidde n. (2017). Cuba's Energy Revolution and 2030 Policy Goals: More Penetration of Renewable Energy in Electricity Generation. International Journal of Cuban Studies; 9(1): 73-90

6) Berris Pérez L. La política energética cubana en el camino del desarrollo sostenible. Energía y tú. 2016; (3)75:4-11

7) Moreno Figueredo C. (2014) La transición hacia 100\% con fuentes renovables de energía. Energía y tú. (1)65:14-17

8) Jain DVK. (2018). Maintaining efficiency of Biogas Energy Plant of Hybrid Model by Using Solar Energy. AJCT; 4(I)

9) Hornborg, A, Cederlöf G, Roos A. (2019). Has Cuba exposed the myth of "free" solar power? Energy, space, and justice. Environment and Planning E: Nature and Space; 2(4): 989-1008

10) Llanes Cedeño, E. (2017). Análisis del ciclo de vida como herramienta para la evaluación del comportamiento ambiental de un proceso. Caso de estudio central eléctrica de fuel oil $110 \mathrm{kv}$ en la provincia de Granma - Cuba. Revista Científica Y Tecnológica UPSE; 4(2)

11) Chernyak, O., Kharlamova, G., Stavytskyy, A. (2018). Trends of International Energy Security Risk Index in European Countries, Baltic Journal of European Studies; 8(1), 5-32 